\title{
Multiple Role of Women Workers In Institution of Social Security Employment
}

\author{
Roziana Ainul Hidayati ${ }^{1}$ \\ Siti Aisyah ${ }^{1}$ \\ ${ }^{1}$ Universitas Muhammadiyah Gresik Indonesia \\ ${ }^{1}$ roziana@umg.ac.id
}

\begin{abstract}
ABSTRAK
Saat ini keberadaan wanita dalam dunia kerja semakin meningkat. Fenomena perempuan memiliki peran ganda tidak dapat disangkal. Kecenderungan perempuan untuk bekerja menimbulkan masalah. Saat bekerja perempuan dihadapkan pada tuntutan pekerjaan, sedangkan saat berada di rumah perempuan akan dihadapkan pada peran domestik. Dalam hal ini ibu yang bekerja dapat memiliki kinerja yang berbeda-beda. Tujuan penelitian ini adalah untuk menganalisis bagaimana kualitas kinerja tenaga kerja perempuan yang memiliki peran ganda di kantor BPJS Ketenagakerjaan Gresik. Metode yang digunakan dalam penelitian ini adalah kualitatif. Informan dalam penelitian ini adalah ibu yang memiliki peran ganda yang memiliki 9 orang anak. Berdasarkan hasil penelitian dan pembahasan tentang kualitas kinerja pekerja perempuan yang memiliki peran ganda, peneliti menyimpulkan bahwa pekerja perempuan yang memiliki peran ganda masih melaksanakan pekerjaannya dengan baik sehingga mencapai kinerja yang optimal.
\end{abstract}

Kata Kunci : konflik peran ganda, kualitas kinerja

\begin{abstract}
Nowadays the existence of women in the world of work is increasing. The phenomenon of women to have a dual role can not be damned. The tendency of women to work raises problems. When working women are faced with the demands of work, while when they are at home women will be faced with domestic roles. In this case working mothers can have different performance. The purpose of this study is to analyze how the quality of the performance of women workers who have a dual role in the BPJS Employment Gresik office. The method used in this study is qualitative. Informants in this study are mothers who have multiple roles who have 9 children. Based on the results of research and discussion on the quality of performance of women workers who have multiple roles, the researchers came to the conclusion that women workers who have multiple roles still carry out their work well so as to achieve optimal performance.
\end{abstract}

Keywords: dual role conflict, quality of performance

\section{INTRODUCTION}

Working is one of the activities carried out by many people to be able to meet their daily needs. Along with the development of times and technological advances, many women are motivated to develop careers by working outside the home. The existence of women in Indonesia in the world of work has also increased. in 2015 the number of the workforce reached $37.78 \%$. In 2016 it increased by $38.16 \%$, and in 2017 it increased by $38.63 \%$. In the past, the role of women was synonymous with household chores such as serving husbands, caring for and caring for children.

Along with the times the role of women has also changed. Women are no longer satisfied with housework so many women enter the career world. The problem is when a married woman decides to work they will have a dual role which can create new problems. The dual role of female workers is also seen at the BPJS Employment Office in Gresik. There are more female employees than men and most of them have a dual role as working mothers as 
well as housewives. Based on interview information with one of the BPJS Employment Gresik employees also said that the problem faced was dual role conflict. When they work sometimes their thoughts are on their children and husband. This makes concentration in the work also disturbed. The distance between home and the office makes them leave earlier than home, and the work that has not been completed also makes them go home longer. This makes the time given to the child and her husband less. They feel they cannot provide enough attention for their child and husband. This can trigger conflicts in the family or work. Conflicts in the family faced such as, for those who live in boarding houses when their child is sick they cannot be beside him to accompany or even care for him. It can also affect their attitude towards work. Occupational conflicts faced such as lack of concentration in work due to family problems faced. When work or family together requires its existence but they cannot fulfill it. This certainly can have an impact on his work. This study aims to analyze how the quality of the performance of women workers who have a dual role in the BPJS Employment Office in Gresik.

\section{LITERATURE REVIEW}

\section{Dual Role Conflict}

According to Robbins (2016: 305) conflict is a process that begins when one party views the other party as having a negative influence on something the first party cares about. So it can be concluded that conflict in general is the meeting of two different interests at the same time and can cause negative effects.

According to Greenhaus and Buttel in (Utaminigsih 2017: 45) defines work-family conflict as a form of conflict between roles where the pressures of work and family roles are not aligned with each other in some ways, where participation in one of these roles becomes more difficult in because of the guidance to participate in other roles.

\section{Quality of Work}

According to Marcana in Hao (2013: 11) states that: "Quality of work is a form of behavior or activities carried out in accordance with expectations and needs or goals achieved effectively and efficiently." Work quality is the reliability in carrying out tasks so that quality is implemented high, right time, careful and with procedures that are easily understood by employees who have great responsibility for the tasks and obligations given, both personal, social, intellectual and moral and spiritual responsibilities. (Hao, 2013: 3)

\section{Performance}

The term performance comes from the word job performance or actual performance (work performance or actual achievement achieved by someone). Mangkunagara (2017: 9) the notion of performance (performance) is the work of the quality and quantity of work achieved by an employee in carrying out their duties in accordance with the responsibilities assigned to him according Mangkunagara (2015:67) factors that affect performance are:

\section{Factor ability (ability)}

Psychologically ability (ability) and ability reality (knowledge and skills) means that employees with IQs above average (110120) with adequate education for their positions and skilled in doing daily work, it will be more easily achieve the expected performance. Therefore employees need to be placed in jobs that match their expertise.

2. Factors Motivation

Motivation takes the form ofattitudean employee'sin dealing withsituationswork. Motivation is a condition that moves employees to be directed towards achieving work goals.

\section{METHODE}

This research uses a qualitative approach. Qualitative research method is a qualitative research method is a research method based on the philosophy of postpositivism, used to examine natural conditions of objects, where researchers are as key instruments, data 
collection techniques are carried out by triangulation (combined), data analysis is inductive or qualitative, and the results of qualitative research emphasize more on the meaning of the generalisai (Sugiyono 2016: 9)

\section{Analysis Unit}

In qualitative research there are only analysis units and informants. This study establishes female workers who have a dual role in the Gresik BPJS Manpower office as an analysis unit.

\section{Informants}

The informants in this study are female workers who have multiple roles and have 9 children.

\section{Types and Sources of Data}

In this study, the source of the data used are primary data and secondary data but prioritizes primary data analysis.

\section{Data Analysis Techniques}

Because this research is a qualitative study, the relevant data analysis technique is a qualitative descriptive analysis technique. In this study using source triangulation with member check as a data validity technique.

\section{Conceptual Framework}

The research framework is shown in figure 1 below:

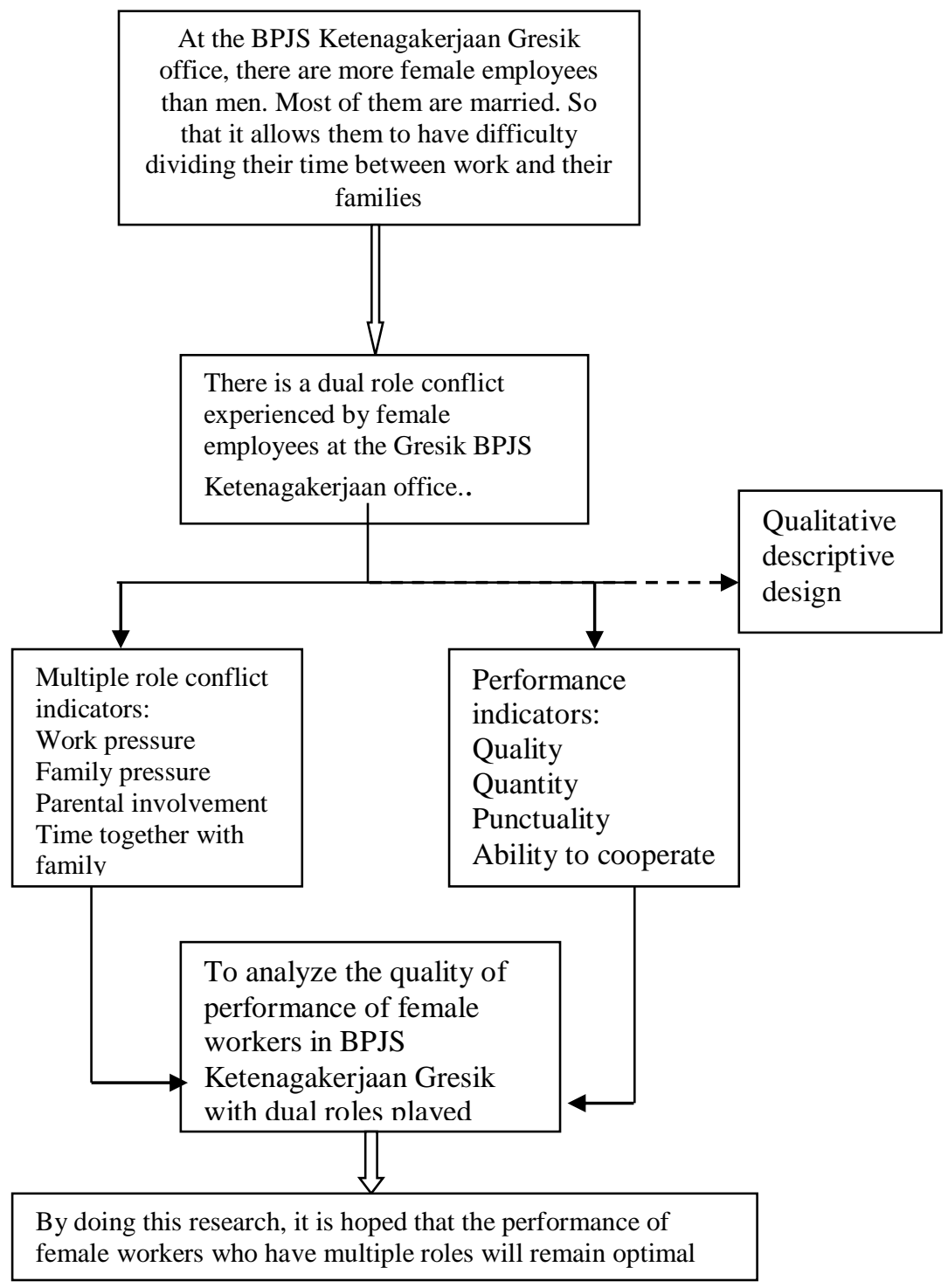

Figure 1: Conceptual Framework 


\section{RESULTS AND DISCUSSION}

A living is not an obligation of a wife or mother. Indeed, it is the responsibility of a husband to be the head of the household, and this stigma has been embedded in people's lives for a long time. Whereas indeed, the duties and responsibilities of fulfilling the economic needs of the family belong to a man or husband. But the current emancipation movement of women makes the noble position of a woman in the family has been evolved by the swift current of globlal which seems to demand that women play a dual role. The dual role of women workers in the Gresik BPJS Employment office is illustrated through two sectors namely the role in the domestic sphere and the role in the public sphere. The role in the domestic sphere is related to their role as a wife and mother and the role in the public sphere is related to their role as a career woman.

Assembled with a role in the domestic realm includes several things related to the reasons women choose to work, a description of a career woman in carrying out a domestic role, caregiving problems and the education of career daughters and family time together. roles in the public sphere include several matters related to discipline, workload of career women, service quality, employee capabilities, and the behavior of a career woman. As a woman who is married even more so when she has children, of course the economic needs of the more, their main reason for work is to help meet economic needs.

As working mothers, of course they cannot carry out the role in the domestic realm fully. They still try to carry out their duties as housewives even though they need help from a housekeeper. Not only that, as working mothers, they certainly cannot pay attention and give full love, just like housewives who are at home completely. As working mothers they delegate the care of their children to those closest to them such as; parents, parents-in-law or siblings and their child's educational learning to tutoring institutions. As a career woman, of course they sacrifice time for her family so that the time together with the family is also reduced and can only gather on holidays.

As a worker they are required to be able to fulfill their duties and responsibilities, one of which is to be able to arrive on time. even though they are burdened with domestic duties, female workers who have multiple roles can still arrive on time. The absence of overtime hours makes them have to manage time flexibly. Sometimes the work that must be done on time must also be done at home. This is one form of their efforts as a career woman to be able to fulfill their duties and responsibilities. Considering they are engaged in quality services, of course service is always prioritized. Standard Operational service procedures provide 3 minutes for RO to provide service processes such as: checking the file submission of claims, information services. but they are able to provide services not to exceed that time.

Related to the timeliness in the process of submitting participant claims, each program in BPJS the time given for disbursement of claims is also different. For the old age insurance program that is given only 5 days, for 3-day death insurance, for 7-day work accident insurance, and for 15-day pension insurance they can also provide it before the maximum limit that has been determined Not only that in supporting the provision of services that are effective and efficient improvement of supporting facilities is also provided for employees.

Improvement of supporting facilities in the form of creating an information system in the form of an online queuing system, online participant reporting system. An improved information system can also reduce participant complaints. If prior to the online queue and online reporting system the participants need to wait for a long queue, but with the improvement of this information system participants can wait for the queue online besides participants who report also do not need to come to the office. This can also make the 
services provided more quickly, effectively and efficiently.

The quality of employees in providing services is also one thing that must be considered. The ability of employees can be seen through how they can carry out their work in accordance with the skills they have. Women workers who have a dual role are also given training for example, excellent service, FGD, balance leadership. By providing training and job desks that are suitable for women workers, they can carry out their work well in accordance with the standards and rules that have been determined. As a career woman, of course faced with a variety of conflicts. Both conflict in the family or conflict in work. Especially for a mother, conflict in the family certainly does not end almost every day. Whether related to children, husband or housework. Not only conflicts in the family, conflicts in work are often faced by a career woman. Work demands and unresolved workloads can also affect their attitudes and behavior both to the participants or even to co-workers and even to the family. they still try to be professional in dealing with various kinds of conflicts. That way they can carry out their work properly.

\section{CONCLUSION}

Based on the description and analysis of data obtained by researchers about the quality of the performance of female workers who have a dual role in the BPJS Employment Gresik office, it can be concluded that female workers who have a dual role in the BPJS Gresik Employment office continue to carry out their work well despite being charged with the task of Gresik. and responsibilities in the domestic sphere they continue to strive to fulfill duties and responsibilities in the public sphere to achieve optimal performance despite having to sacrifice many things for their families. Women workers who have double paran can still achieve optimal performance.

Based on the conclusions of the results of the study it can be recommended as follows:
For the Gresik Employment BPJS office it is necessary to obtain a solution in the form of work time which is balanced by reward and punishment. For example in a way; a salary deduction if they arrive late and a bonus for those who can reach the target.

For further researchers there are limitations related to the multiple roles so that they can conduct deeper research related to the dual role phenomenon and this research can be made a reference to conduct further research using different techniques.

\section{REFERENCES}

Deviani, rina, 2011, The Role of Lecturers Women at the University of Sultan Ageng Tirtayasa, jurnal.untirta.ac.id

Frone, M. R, Rusell. M., Cooper, ML, 1992. Antecedent And Outcomes Of Work Family Conflict: Testing A Model Of The Work Family Conflict Interface. Journal of Appliaed Psychology, 65-75

Greenhaus, JH, Beutell, NJ (1985). Source of Conflict Between Work and Family Roles, the academy of management, Vol.10 No 1, 76-86

Hennesy, KD2005. Work-family conflict selfefficacy: Ascale http://drum.umd.edu/dspace/bitstream/19 03/2526/1/umi-umd-2410.pdf

Indriyani, 2009, Effects of Dual Role Conflict and Work Stress on Nurse Performance Women's Hospital, eprimts.undip.ac.id

Iswari,Pradhanawati,2017 Effect of Dual Role

Stress Work And Work Motivation on Employee performance at PT Pharos Tbk Semarang, p 8 ejournal3.undip.ac.id, Mangkunagara, anwarprabu, 2017 , HR

Performance Evaluation, Refika Aditama, Bandung

Marretih, Anggla. KE, 2013, Work Family Conflict (Phenomenology Study in Gender and Mental Health Prespectives)Social and Cultural

MoherionoJournal, 2012, Competency-Based Performance Measurement, Rajagrafindo, Jakarta 
Nawawi, Hadari, 2011 Human Resource Management for Competitive Business, Gajah Mada University Press, 8th Cet, Yogyakarta

Netemeyer, RG, Boles, JS, \& Mc Murrian, R. (1996). Development and Validation of Work-Family Conflict and Family Work Conflict Scales. Journal of Applied Psychology, 81, 400-410.

Robbins, SP, 1996 Managing Organizational Conflict. Pretince Hall, Englewold Clift, New york

Rosita, 2012, Influence of Dual Role Conflict and Job Stress on Performance Lecturer Faculty of Economics, University Women In Jambi, hal.187 ejournal.umm.ac.id

Sugiyono, 2016 Quantitative Research Methods, Qualitative and $\mathrm{R} \& \mathrm{D}$, alfabeta, Bandung

Widodo, (2015). "Human Resource Development Management". Yogyakarta Student Library Publisher: 